\title{
Surgical stress and cancer progression: the twisted tango
}

\author{
Zhiwei Chen ${ }^{1 \dagger}$, Peidong Zhang ${ }^{1 \dagger}$, Ya Xu ${ }^{1,2+}$, Jiahui Yan ${ }^{1}$, Zixuan Liư ${ }^{1}$, Wayne Bond Lau ${ }^{3}$, Bonnie Lau ${ }^{4}$, Ying Li ${ }^{5}$, \\ Xia Zhao ${ }^{1}$, Yuquan $\mathrm{Wei}^{1}$ and Shengtao Zhou ${ }^{1 *}$ (D)
}

\begin{abstract}
Surgical resection is an important avenue for cancer treatment, which, in most cases, can effectively alleviate the patient symptoms. However, accumulating evidence has documented that surgical resection potentially enhances metastatic seeding of tumor cells. In this review, we revisit the literature on surgical stress, and outline the mechanisms by which surgical stress, including ischemia/reperfusion injury, activation of sympathetic nervous system, inflammation, systemically hypercoagulable state, immune suppression and effects of anesthetic agents, promotes tumor metastasis. We also propose preventive strategies or resolution of tumor metastasis caused by surgical stress.
\end{abstract}

Keywords: surgical stress, cancer, circulating tumor cells (CTCS), disseminated tumor cells (DTCs), ischemia/ reperfusion injury (IRI), inflammation, nervous system, immunosuppression, coagulation system

\section{Introduction}

Surgical resection remains to be a mainstay of cancer treatment. However, cancer recurs in many patients after a short time. For example, $25 \%$ to $30 \%$ of colorectal cancer patients who do not have visible evidence of metastasis during diagnosis are detected to develop metastasis within 5 years [1]. Evidence from animal and clinical trials has demonstrated that surgery-induced stress is a powerful factor promoting malignant cancer growth [2]. Surgery-induced stress is a systemic effect, involving inflammation, ischemia-reperfusion injury (IRI), sympathetic nervous system activation, and increased cytokine release, altogether significantly increasing cancer recurrence risk (Fig. 1).

Cells of a tumor can disseminate in peripheral blood as circulating tumor cells (CTCs), or migrate to the bone marrow or lymph nodes as disseminated tumor cells (DTCs), capable of surviving chemotherapy and initiating tumor regrowth [3]. The systemic body response to surgery may provide an environment favorable for tumor metastasis, induced by a

\footnotetext{
* Correspondence: taotaovip2005@163.com

${ }^{\dagger}$ Zhiwei Chen, Peidong Zhang and Ya Xu contributed equally to this work. ${ }^{1}$ Department of Obstetrics and Gynecology, Key Laboratory of Birth Defects and Related Diseases of Women and Children of MOE and State Key Laboratory of Biotherapy, West China Second University Hospital, Sichuan University and Collaborative Innovation Center, 610041 Chengdu, Sichuan, People's Republic of China

Full list of author information is available at the end of the article
}

protracted period of immunosuppression and upregulation of adhesion molecules (Fig. 2). Clinical trials have detected increased CTCs and DTCs in many cancer types, including gastric [4], lung [5], breast [6], hepatocellular [7], and colorectal [8] cancers. When tumor cells disseminate to a new environment, they may remain dormant for several years or even several decades rather than regrow immediately [9]. One recent study in breast cancer patients demonstrates such dormant cells awakening after surgery, initiating metastasis [10].

In this review, we will summarize previous research, discuss the possible effects of surgical stress on cancer progression, and analyze the responsible mechanisms. We will also present the available therapeutics that can prevent or mitigate surgical stress to improve patient outcomes.

\section{Surgery-induced cancer cell dissemination}

Tumor cells have been known to disseminate into the vascular and lymphatic system, migrating to distant organs and initiating tumor regrowth and recurrence [3]. Clinical evidence has detected CTCs in the blood and DTCs in the bone marrow and lymph nodes; their population is an important indicator for diagnosis, prognosis, and therapeutic response in hepatocellular, breast, brain, and esophageal cancers [11-15]. CTC numbers increase following surgery for gastric [4], lung [5], breast [6], hepatocellular [7] and 
Immune suppression

Treg cells, neutrophils $\uparrow$ NK cells $\downarrow$

Isoflurane, ketamine, thiopental sodium, et al
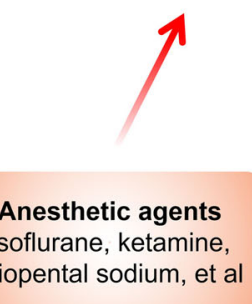

\section{$\leftarrow$}

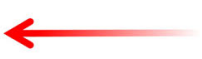

Inflammation

IL-1, TNF- $\alpha$, VEGF, MMPs, PEG2 $\uparrow$

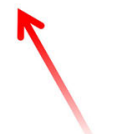

Sympathetic nervour system

Catecholamine $\uparrow$
Cancer recurrence after surgery

Circulatory system Hypercoagulable state, ischemia/reperfusion injury

Fig. 1 Factors that promote cancer recurrence after surgery and the interactions between them

colorectal [8] cancers, and are associated with poor survival. DTCs found in sentinel lymph nodes have been noted to quadruple on average after breast cancer surgery [16]. Surgery promotes tumor cell migration in a complex fashion involving inflammatory factors, catecholamines, and pro-metastatic enzymes. Of note, after 'curative' surgery, disseminated cancer cells exhibit extreme genomic heterogeneity before initiating metastasis. This heterogeneity decreases later, and is induced by selected clonal expansion [17]. This phenomenon indicates that disseminated cells have not yet acquired all the key hallmarks of fully malignant cells.

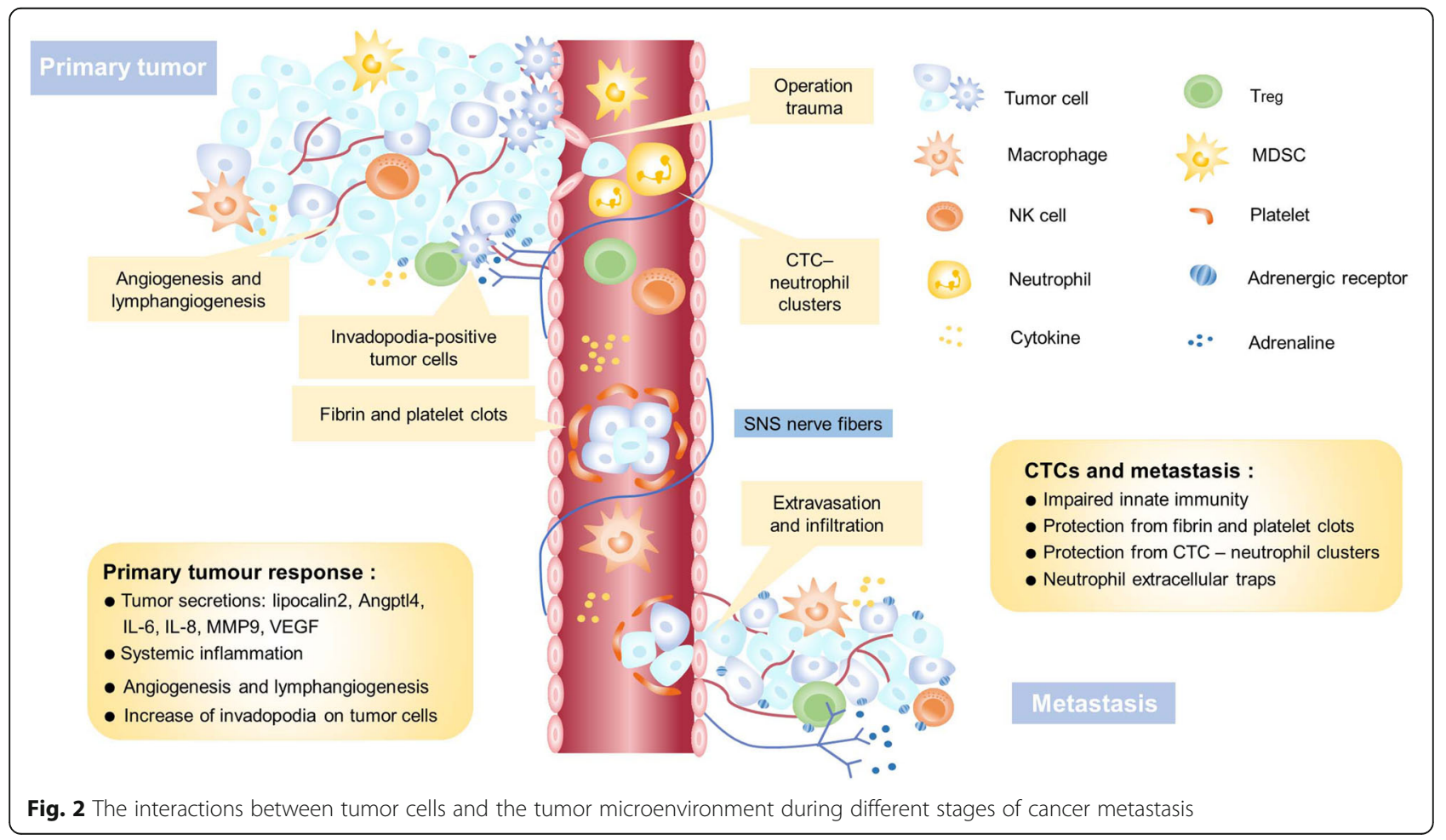




\section{Ischemia/reperfusion injury (IRI)}

Ischemia/reperfusion injury (IRI) often occurs in surgeries involving hepatocellular carcinoma (HCC) and liver transplantation [18, 19]. In a clinical trial of 103 liver transplant patients with HCC, IRI was associated with tumor recurrence, and extended ischemic duration exacerbated HCC recurrence risk [19]. Many signaling pathways affecting protein expression change after IRI. For instance, IRI enhances the expression of TLR9, a promoter of NF-kb and ICAM-1 [20]. The CD95/CD95L pathway, usually regarded as a pathway inducing cell death, promotes tumor cell proliferation by signaling axis such as KRAS. In the liver, the CD95/CD95L pathway is upregulated in many cell types during IRI, resulting in the apoptosis of hepatocytes and infiltrating cytotoxic lymphocytes, contributing to tumor progression [21].

IRI also modifies the secretome (e.g lipocalin2, Angptl4) of tumor cells $[22,23]$. Hypoxia and inflammation could upregulate lipocalin2 (LCN2) in many cancers, promoting tumor cell survival, proliferation, and metastasis by inducing EMT (epithelial-mesenchymal transition) and eliminating the iron ion [22, 24]. In addition, IRI affects the tumor microenvironment, cultivating a better "soil" for tumor growth, migration, and adhesion. The chemokine CXCL10 secreted by monocytes, endothelial cells, and fibroblasts has a lethal effect upon tumor cells [25]. However, the endothelial progenitor cell (EPC) is mobilized by CXCL10/CXCR3 signaling after small liver grafts, promoting angiogenesis and tumor growth [26]. Matrix metallopeptidase 9 (MMP-9) is unregulated after IRI and promotes micrometastasis of colorectal carcinoma, and may represent a therapeutic target against IRI -induced tumor growth and metastasis [27, 28]. IRI also increases E-selectin, present in the endothelium, which is critical for tumor cell adhesion, and has been shown to mediate liver metastasis of pancreatic cancer [29]. Additionally, IRI contributes to tumor metastasis by its effects upon neutrophils, detailed later in this review [30].

\section{Sympathetic nervous system activation}

The autonomic nervous system primarily regulates the body's unconscious physiologic functions. The sympathetic nervous system stimulates the body's fight-or-flight response, modifying blood flow and cytokine secretion $[31,32]$. Sympathetic nervous system activation remains one of the most overt pathophysiological responses to surgical stress, in turn sharply increasing circulating catecholamines [33]. Tissue trauma during surgery, hypothermia, patient anxiety, metabolic derangements, and fasting all may be perioperative triggers [34].

Increase of circulating catecholamine (including adrenaline and noradrenaline) levels activates $\beta$-adrenoceptors $(\beta \mathrm{AR})$. Activation of $\beta \mathrm{AR}$ directly affects tumor cells and indirectly remodels the tumor microenvironment [32, 35-37]. $\beta A R$ activation increases metastasis in breast, lung, and colon cancer models, and accelerates growth in mammary tumors [38]. In addition, $\beta A R$ activation also structurally changes tumor cells. Initial tumor cells have a defined shape and deformability. $\beta A R$ activation increases the frequency of invadopodia-positive tumor cells and the number of invadopodia per cell [39]. Invadopodia are specialized actin-rich structures that facilitate invasion through the basement membrane and surrounding stroma [40]. The formation of invadopodia increases tumor cell invasiveness through the three-dimensional extracellular matrix, enhancing development of metastasis and cancer recurrence. In mammary tumors, $\beta$ AR activation is associated with accelerated tumor growth [41]. In a colon carcinoma cell line, catecholamines induce in vitro locomotion in a $\beta 2$ adrenoceptor-dependent fashion [42].

The communication between tumor cells and the microenvironment drives tumor progression [43]. Production of several pro-metastatic factors is increased in the tumor microenvironment, including matrix metalloproteinase 9 (MMP9), vascular endothelial growth factor (VEGF), IL-8, and IL- 6 [44, 45]. These cytokines, increased by the autonomic nervous system activation, stimulate tumor growth by triggering inflammatory responses and promoting angiogenesis [46]. After $\beta A R$ activation, inflammation-dependent mechanisms remodel tumor-associated lymphatic and blood vasculature, which in turn promote in vivo tumor cell dissemination [36]. Also, accumulating evidence has suggested that catecholamines have a stronger effect upon the immune system than glucocorticoids, and activation of the sympathetic nervous system suppresses natural killer cell response to tumor cells $[47,48]$.

\section{Inflammation}

Surgery induces inflammation by many means, including direct wound formation [49] and infection, resulting in the release of many inflammatory mediators and the recruitment of numerous immune cell types, particularly monocytes and neutrophils [50]. Factors such as IL-1, TNF- $\alpha$, VEGF, and matrix metalloproteinases (MMPs), secreted by recruited macrophages and neutrophils, all contribute to tumor progression $[50,51]$. Produced by cyclooxygenase, prostaglandin E2 (PGE2) modulates various physiologic and pathologic activities, such as cell proliferation and angiogenesis $[52,53]$. PGE2 promotes neoplastic progression in various malignancies. In lung cancer, PGE2 promotes metastasis by increasing MMP9 mRNA expression and inhibiting E-cadherin mRNA expression [54]. PGE2 also induces an immunosuppressive response, including increasing cancer-promoting regulatory $\mathrm{T}$ (Treg) cells, reducing the activated $\mathrm{CD}^{+} \mathrm{T}$ cell population, and altering the cytokines secreted by $\mathrm{T}$ helper cells $[55,56]$. In breast cancer, PGE2 plays a key role in the "dormantto-proliferative" transition when tumor cells disseminate to the bone microenvironment [57]. This may explain the 
clinical observations that inhibiting cyclooxygenase-2 (COX-2) mediates antineoplastic effects in some prostate or lung cancer patients $[58,59]$.

While the complement system was once regarded as an effective anti-cancer defense, significant work in recent years has identified that complement elements may promote tumor growth during chronic inflammation [60] via multiple mechanisms, such as enhancing the stemness of cancer stem cells [61], promoting angiogenesis [62, 63], and reducing anti-tumor immunity [64-66]. Surgeryinduced inflammation activates the complement system, contributing to tumor recurrence. Increased levels of C3a and terminal complement complex (TCC) are observed on the second postoperative day of thoracoabdominal esophagectomy [67], a phenomenon exhibited in patients subjected to major abdominal surgery [68]. Tibial fracture surgery performed in a mouse model increases C3 levels and C3a receptor expression in hippocampal astrocytes and microglia postoperation [69]. Therefore, targeting the complement system may be an effective strategy mitigating surgical stress for cancer patients.

\section{Hypercoagulable state}

In the normal state, few circulating tumor cells successfully colonize in new sites due to the lack of extracellular matrix support, and damage by shear stress or the immune surveillance [70]. Blood of a hypercoagulable state protects tumor cells from the above risks [71-73]. Surgery induces the release of pro-inflammatory cytokines such as IL-1, IL-6, and TNF, which increase the production of fibrinogen [71]. Besides, surgery promotes fibrin and platelet clots around tumor cells, which act as a coat of protection against detection and attack by NK cells $[72,74]$ and mediate tumor cell adherence to endothelial cells, releasing proangiogenic and mitogenic factors [74]. Trials demonstrate that anticoagulants can damage the fibrin/platelet coat, reduce tumor metastasis, and may significantly decrease metastatic disease after cancer surgery [72].

Platelets are crucial for hemostasis and wound healing. However, platelets contribute to tumor metastasis [75] and may be associated with decreased survival [76, 77]. A recent study demonstrates that platelets are increased in the perioperative period, and is associated with poor cancer outcomes [78]. Many mechanisms exist by which platelets are protective of tumor cells, such as cloaking tumor cells to avoid NK cell detection, promoting the arrest of tumor cells to endothelial cells, enhancing the development of secondary lesions and mediating angiogenesis $[75,79,80]$.

\section{Immune suppressive state}

Tumor cells can be protected from attack by establishing immune suppression, a long considered critical step in both tumor formation and progression [81]. Surgery provides numerous factors (inflammation, blood transfusion, and anesthetic agents) further buttressing a systemic immunosuppressive state. The immunosuppressive state after surgery can span for about two weeks [82, 83], peaking day 3 postoperative [2]. In this section, we will revisit the immunosuppressive effects of surgery, by analysis of the four main involved immune cell types.

\section{Regulatory T cells}

Evidence supports a role for Treg cells in the establishment of immunosuppression within the primary tumor, as well as tumor cell dissemination and metastasis. Increased Treg cell population has been detected in multiple cancers, correlated with poor prognosis [84-87]. It was reported that Treg cells are markedly increased postoperatively, accompanied by decreased $\mathrm{T}$ helper cells and cytotoxic $\mathrm{T}$ cells. These factors benefit survival of neoplastic cells to varying degrees, depending upon the operative procedures performed [82, 87-89]. By unclear mechanisms, modifying $\mathrm{T}$ cell populations may therefore prevent cancer recurrence [90]. Hypersecretion of cortisol and overproduction of immunosuppressive acidic proteins are observed systemically after surgery [82], and may be responsible for the differential modification of $\mathrm{T}$ cell subpopulations.

\section{Myeloid-derived suppressor cells (MDSCs)}

Accumulating evidence has demonstrated that number of myeloid-derived suppressor cells (MDSCs) after surgery correlates with cancer recurrence and indicates a poor prognosis [91-93]. Particularly, CD $11 b^{+}{ }^{C D} 33^{+}$HLA-DR $^{-}$MDSCs significantly increase in lung cancer patients after thoracotomy, and are more efficient in secreting MMP-9, promoting angiogenesis and tumor growth than MDSCs isolated before surgical operation in allograft tumor model [94]. MDSCs regulate tumor progression through various ways, including participating in the formation of premetastatic niches, promoting angiogenesis and tumor cell invasion [95]. Phosphodiesterase-5 inhibitors, such as sildenafil, could hamper the functions of surgery-derived MDSCs through downregulating the expression of arginase 1 (ARG1), IL4Ra and reactive oxygen species (ROS), enabling NK cell tumoricidal activity and reducing postoperative disease recurrence [96].

\section{NK cells}

Surgery alters the function of NK cells, cytotoxic lymphocytes that scavenge malignant cells. In the perioperative period, natural killer cell cytotoxicity (NKC) and NK cell IFNy secretion are both profoundly suppressed [97, 98], which might be directly induced by catecholamine, glucocorticoid (CORT), and prostaglandin (PG) [99, 100]. Surgical stress affects immune cytotoxicity by directly exerting "toxic" effects upon NK cells, which impair programmed tumor lysis in sarcoma and solid tumor patients [101]. As mentioned above, surgery also promotes the cloaking 
fibrin/platelet coat around tumor cells, impairing NK cellmediated tumor clearance [72].

\section{Neutrophils}

Protecting the body from foreign pathogens, neutrophils neutralize harmful microorganisms, and are also the main mediator of inflammation. However, neutrophils have been demonstrated to promote tumor cell metastasis both in vitro and in vivo [102, 103]. Neutrophils escort "hitchhiker" CTCs to the whole body by multiple mechanisms [3]. They can interact with CTCs and form the circulating tumor cell-white blood cell (CTC-WBC) cluster, driving cell cycle progression systemically, expanding the CTC metastatic potential [104]. Surgery induces systemic inflammation, activating neutrophils, thereby providing favorable migration conditions for CTC [105].

During microorganism invasion, neutrophils can release neutrophils extracellular traps (NETs) into the extracellular space for invader capture [106]. NETs play a positive role in innate immunity, clearing bacteria and fungi. However, NETs can trigger HMGB1 (High mobility group box 1) release, activating TLR9-dependent pathways in cancer cells, thereby promoting tumor cell adhesion, proliferation, migration, and invasion after surgical stress [107]. Metastatic dormancy has long complicated breast cancer treatment. NETs awaken dormant cancer cells in mice during inflammation, and promote the development after surgery, in the setting of increased neutrophils. As inflammation is a significant character of surgery and IRI, NETs may be implicated in surgical stress induced cancer cell dormancy revival [10, 108, 109]. It should be noted that not all effects upon the immune system are caused by surgery-induced trauma. In our next section, we discuss the anesthetic techniques reported to promote tumor growth and metastasis by reducing NK cell activity and abundance [110].

\section{Anesthetic agent effects}

The effects of anesthetic agents upon tumor cells have been documented since the early 1980s [111]. Most anesthetic (inhaled or intravenous alike) agents contribute to tumor recurrence by directly impacting tumor cell signaling pathways or by indirectly impacting neuroendocrine and immune function [112].

\section{Inhalational anesthetics}

Some inhalational anesthetics accelerate tumor progression. Isoflurane is a classic inhaled halogenated hydrocarbon anesthetic used for general anesthesia that inhibits activated potassium channel conduction [113]. Renal cell carcinoma cells (RCC4) proliferate and migrate more rapidly when exposed to $2 \%$ isoflurane in vitro [114]. Furthermore, isoflurane induces increased expression of hypoxia-inducing factors 1 and 2 (HIF1, HIF2), sequentially promoting tumor recurrence by stimulating cellular protection or primary pathogenesis of residual cells [112]. Th1:Th2 ratio [115] and NK cell activity [116] are both altered after isoflurane exposure, resulting in increased tumor cell migration [117].

Nitrous oxide acts upon a wide range of receptors [118, 119], and is associated with accelerated progression of lung and liver metastasis in mouse models. It has the strongest liver metastatic stimulation of any anesthetic studied [110, 120]. Such effects of volatile anesthesia has been recognized in clinical studies, which document markedly reduced overall survival of patients subjected to cancer surgery, even after controlling for comorbidity risk and the presence of metastatic disease [121]. This suggests limiting use of inhalational anesthetics in the setting of cancer surgery.

\section{Intravenous anesthetics}

Some intravenous anesthetics have been demonstrated to contribute to tumor growth and metastasis, albeit via unclear mechanisms. Ketamine is an intravenous anesthetic which induces a trance-like state while providing pain relief, sedation, and amnesia [122] by blockade of the NMDA receptor, an ionotropic glutamate receptor [123]. Ketamine reduces the activity of NK cells, and more than doubles the survival and metastasis rate of lung tumors [124]. Increased lung tumor retention was reported after exposure to a volatile anesthetic (halothane) or intravenous agents (ketamine and thiopental) before intravenous inoculation with MADB106 breast cancer cells in rats [112].

Thiopental sodium is a highly oleophilic intravenous barbiturate anesthetic acting upon the $\mathrm{GABA}_{\mathrm{A}}$ receptor channel [125]. Thiopental significantly reduced NK cell activity and increased survival of MADB106 lung tumor cells or the probability of lung metastasis [124]. Thiopental sodium inhibits the cascade reaction of NF- $\mathrm{kB}$ activation signal by modifying I $\mathrm{B}$ kinase activity, in which the thio-group at the position of barbiturate molecule C2 plays a key role [126].

Propofol, a short-acting intravenous anesthetic of alkyl acids, has anti-cancer effects. Propofol inhibits the capacity of cancer cells for migration and invasion by impairing translation of mRNA and modulating the GTPase RhoA $[127,128]$. The conjugation of propofol - DHA or propofol - EPA can significantly inhibit the adhesion (15-30\%) and migration (about 50\%) of breast cancer cells, and induce apoptosis (about 40\%) [129]. A retrospective study from a UK group reported a $5 \%$ improved overall survival at 5 years in 2607 patients (after propensity score matching) exposed to propofol-based intravenous anesthesia compared to volatile anesthesia. Multivariate analysis by cancer type reveals that improved survival was predominantly observed in gastrointestinal and urological cancer subtypes [121].

Additionally, the method of anesthetic administration impacts cancer recurrence. Regional anesthesia (RA) refers to local anesthetic administration blocking transmission of 
nociceptive stimuli during tissue injury [112]. RA reduces the recurrence rate of breast cancer, prostate cancer, ovarian cancer, melanoma, and localized colon cancer, and improves overall survival rate [130]. Epidural anesthesia reduces the recurrence rate after radical prostatectomy by $57 \%$ after accounting for known prognostic factors [131].

\section{Therapy by pharmaceutical agents}

Many pharmaceutical agents have been developed to mitigate surgical stress-induced tumor progression (Table 1). Clinical studies investigating propranolol and metoprolol demonstrate that $\beta$-blockers, which are a classical antihypertensive class of drugs, significantly inhibit tumor progression [132, 133]. In a clinical trial of 185 high-grade epithelial ovarian carcinoma patients, the overall survival (OS) of patients given $\beta$ blockers after surgery was significantly increased compared to the control group after primary cytoreductive surgery [134]. In another trial, perioperative $\beta$-blockade significantly inhibits recurrence and metastasis of triple-negative breast cancer [135]. Patients undergoing radical mastectomy surgery exhibit increased levels of circulating epinephrine, norepinephrine, PGE 2, peripheral FOXP3 mRNA, and Treg populations; daily propranolol $(60 \mathrm{mg})$ decreased Treg elevation, underlining surgery-induced catecholamines promotion of Tregs [136, 137]. Propranolol also inhibits thromboxane synthesis and reduces platelet aggregation, further contributing to its anti- metastatic properties [154]. More clinical trials assessing the effects of $\beta$-blockers upon oncologic outcomes during the perioperative period in patients with breast, ovarian, colorectal, or skin (melanoma) cancers remain ongoing [155].

Non-steroidal anti-inflammatory drugs (NSAIDs), which inhibit cyclooxygenase 1 or 2 (COX-1 or COX-2), are widely used clinically for anti-inflammatory or analgesic effect. NSAIDs effectively inhibit surgery-induced systemic inflammation, eliminating suppression of NK cell populations, preventing tumor growth and metastasis [10, 156, 157]. However, the effects of NSAIDs are very limited. For example, many reports demonstrate that celecoxib, a COX2 specific inhibitor, did not significantly affect apoptosis in prostate, breast cancer, and cervical intraepithelial neoplasia [158-161], and may only prevent colorectal adenomas [138]. Parecoxib, another COX2 inhibitor, is similarly temporally limited. Although parecoxib is an excellent analgesic in hepatocellular carcinoma [162] and has immunoprotective effect against cervical cancer [139], IL-6, IL-8, and TNF- $\alpha$ production is unaffected in patients receiving parecoxib 24 hours after colorectal surgery [163]. In a trial of 154 women between the ages of 25 and 65 undergoing a modified radical mastectomy for primary breast cancer, a single treatment of parecoxib did not prevent Treg elevation; propranolol plus parecoxib treatment exhibited no additive or synergistic effects compared to propranolol treatment alone [136].

Recently, rapid developments of immunotherapy have given it clinical applications. Many immunotherapy drugs inhibit surgery-induced suppression of immune cells. Tolllike receptors (TLR), which play a crucial role in activating the innate immune system, are expressed on the membranes of leukocytes and even some non-immune cells [164]. Both TLR4 agonist GLA-SE and TLR9 agonist CpG-C oligodeoxynucleotides significantly decrease cancer metastasis by increasing NK cell cytotoxicity during the perioperative period in a mouse model without adverse effects [142, 143]. Vaccines, the classic immune activators, have also been tried in combination with surgery. Perioperative treatment with influenza vaccination reversed surgery-induced dysfunction in natural killer cells

Table 1 Therapeutic regimens to prevent cancer recurrence after surgery

\begin{tabular}{|c|c|c|c|c|}
\hline Drug & Description & $\begin{array}{l}\text { Perioperative } \\
\text { anti-tumor mechanism }\end{array}$ & Examples & Reference \\
\hline $\begin{array}{l}\text {-adrenoceptor antagonists } \\
\text { ( } \beta \text {-blockers) }\end{array}$ & $\begin{array}{l}\text { Inhibitor of } \beta \text {-adrenoceptors; used to treat } \\
\text { heart failure, tachycardia, and hypertension }\end{array}$ & $\begin{array}{l}\text { Blockade of stress-induced } \\
\text { catecholamine release }\end{array}$ & Propranolol, Metoprolol & {$[132-137]$} \\
\hline NSAIDS & $\begin{array}{l}\text { Inhibitor of cyclo-oxygenase; use to reduce } \\
\text { pain, fever, inflammation, and prevent } \\
\text { blood clots }\end{array}$ & Inhibition of COX-2 & $\begin{array}{l}\text { Aspirin, Meloxicam, } \\
\text { Celecoxib, Parecoxib }\end{array}$ & {$[10,138-141]$} \\
\hline PDE-5 inhibitors & $\begin{array}{l}\text { Inhibitor of PDE-5, conventionally used to } \\
\text { treat erectile dysfunction }\end{array}$ & $\begin{array}{l}\text { Downregulation of ARG1, } \\
\text { IL4Ra and ROS expression }\end{array}$ & Sildenafil, Tadalafil & {$[96]$} \\
\hline Immunostimulants & $\begin{array}{l}\text { Many diseases such as malignancy will } \\
\text { stimulate the immune system }\end{array}$ & $\begin{array}{l}\text { Activation of immune cells } \\
\text { (e.g. NK cells) }\end{array}$ & $\begin{array}{l}\text { Toll-like receptor agonists, } \\
\text { vaccines, checkpoint inhibitors }\end{array}$ & {$[142-148]$} \\
\hline Statins & Lipid-lowering medications & $\begin{array}{l}\text { Inhibition of } \mathrm{HMG}-\mathrm{CoA} \\
\text { reductase or cholesterol } \\
\text { synthesis }\end{array}$ & Fluvastatin & [149] \\
\hline Anticoagulants & Inhibit thrombosis & $\begin{array}{l}\text { Inhibit formation of fibrin } \\
\text { and platelet clots }\end{array}$ & Aspirin, heparin, warfarin & {$[72,150-152]$} \\
\hline Bevacizumab & Inhibits angiogenesis & Inhibits VEGF & Bevacizumab & [153] \\
\hline
\end{tabular}

Abbrevations: NSAIDs, nonsteroidal anti-inflammatory drugs; COX-2, Cyclooxygenase 2; NK, natural killer; HMG-CoA, $\beta$-Hydroxy $\beta$-methylglutaryl-CoA; VEGF, Vascular endothelial growth factor; PDE-5, Phosphodiesterase-5; ARG1, Arginase 1; ROS, reactive oxygen species 
and reduced postoperative metastatic disease in the mouse [144]. In another trial, oncolytic Newcastle Disease Virus (NDV) was employed to infect multiple autologous tumor cell types ex vivo. Postoperative injection of this OV modified tumor vaccine significantly enhanced survival in vaccinated patients compared to unvaccinated cohorts [145-147]. Checkpoint inhibitors against PD-1 mitigate postoperative T-cell dysfunction. In combination with prostaglandin inhibitors, these agents restore postoperative T-cell function completely, indicating the potential of immunotherapy in surgical stress and tumor therapy [148].

Statins, a class of agents commonly used to control hyperlipidemia, have pleiotropic effects including antiinflammatory, antioxidative, and vasodilatatory effects, improving endothelial function, stabilizing atherosclerotic plaques, and ultimately have anti-tumor effects, albeit via imprecisely understood mechanisms [149]. The antimetastatic properties of anticoagulation agents have been demonstrated in various animal models [72, 150, 151]. Antithrombotics such as aspirin, heparin, and warfarin have clinically been demonstrated to improve cancer patient survival [152], supporting their important application to prevent metastasis during surgery. Perioperative administration of bevacizumab improved survival in a clinical trial of 223 patients following lung metastasectomy for colorectal cancer [153].

\section{Conclusions}

Surgery remains a common and important treatment for patients with solid tumors. However, despite advanced technology, new procedures, and advanced equipment availability, surgery might not significantly improve every cancer patient's condition. In this review, we have discussed various etiologies of poor outcome in patients having undergone surgical stress during tumor removal. Innovative therapeutic solutions are in development to improve outcomes after cancer-related surgical procedures. Rigorous future evaluation of the efficacy and feasibility of these therapeutic avenues in cancer patients post operatively are warranted.

\section{Acknowledgements}

Not applicable.

\author{
Authors' contributions \\ ZWC, PDZ, YX, XZ, YQW, and STZ designed this study. ZWC, PDZ, YX, JHY \\ $Z X L$, and $Y L$ drafted the manuscript. WBL and $B L$ revised this manuscript. \\ ZWC and PDZ drew the figures. All authors read and approved the final \\ manuscript.
}

\section{Funding}

This work was supported by grants from National Natural Science Foundation of China(grant \#81822034 and grant \#81773119), National Key Research and Development Program of China(grant \#2018YFA0109200 and grant \#2017YFA0106800), Sichuan Science-Technology International Cooperation Project (grant \#2019YFH0144), and Direct Scientific Research Grants from West China Second Hospital, Sichuan University(grant \#KS021).
Availability of data and materials

Not applicable.

Ethics approval and consent to participate

Not applicable.

\section{Consent for publication}

All of the authors are aware of and agree to the content of the paper and their being listed as a co-author of the paper.

\section{Competing interests}

The authors declare that they have no competing interests.

\section{Author details}

${ }^{1}$ Department of Obstetrics and Gynecology, Key Laboratory of Birth Defects and Related Diseases of Women and Children of MOE and State Key Laboratory of Biotherapy, West China Second University Hospital, Sichuan University and Collaborative Innovation Center, 610041 Chengdu, Sichuan, People's Republic of China. Deyang People's Hospital, Deyang, Sichuan, People's Republic of China. ${ }^{3}$ Department of Emergency Medicine, Thomas Jefferson University Hospital, Philadelphia, USA. ${ }^{4}$ Department of Surgery, Emergency Medicine, Kaiser Santa Clara Medical Center, Affiliate of Stanford University, Stanford, USA. ${ }^{5}$ Department of Biomedical Sciences, City University of Hong Kong, Kowloon Tong, Hong Kong, People's Republic of China.

Received: 18 June 2019 Accepted: 14 August 2019

Published online: 02 September 2019

\section{References}

1. van der Bij GJ, Oosterling SJ, Beelen RHJ, Meijer S, Coffey JC, van Egmond $M$. The perioperative period is an underutilized window of therapeutic opportunity in patients with colorectal cancer. Ann Surg. 2009;249:727-34.

2. Coffey JC, Wang JH, Smith MJF, Bouchier-Hayes D, Cotter TG, Redmond HP. Excisional surgery for cancer cure: therapy at a cost. Lancet Oncol. 2003:4:760-8.

3. Mohme M, Riethdorf S, Pantel K. Circulating and disseminated tumour cells - mechanisms of immune surveillance and escape. Nat Rev Clin Oncol. 2017;14:155-67.

4. Zhang Q, Shan F, Li Z, Gao J, Li Y, Shen L, Ji J, Lu M. A prospective study on the changes and clinical significance of pre-operative and post-operative circulating tumor cells in resectable gastric cancer. J Transl Med. 2018;16:171.

5. Duan XC, Zhu YJ, Cui Y, Yang ZR, Zhou SJ, Han Y, Yu DP, Xiao N, Cao XQ, Li YS, et al. Circulating tumor cells in the pulmonary vein increase significantly after lobectomy: A prospective observational study. Thor Cancer. 2019;10:163-9.

6. Brown DC, Purushotham AD, Birnie GD, George WD. Detection of intraoperative tumor-cell dissemination in patients with breast-cancer by use of reverse transcription and polymerase chain-reaction. Surgery. 1995;117:96-101.

7. Ou HH, Huang Y, Xiang LY, Chen ZJ, Fang YH, Lin YX, Cui ZL, Yu S, Li XH, Yang $\mathrm{DH}$. Circulating tumor cell phenotype indicates poor survival and recurrence after surgery for hepatocellular carcinoma. Dig Dis Sci. 2018;63:2373-80.

8. Peach G, Kim C, Zacharakis E, Purkayastha S, Ziprin P. Prognostic significance of circulating tumour cells following surgical resection of colorectal cancers: a systematic review. Brit J Cancer. 2010;102:1327-34.

9. Endo H, Inoue M. Dormancy in cancer. Cancer Sci. 2019;110:474-80.

10. Krall JA, Reinhardt F, Mercury OA, Pattabiraman DR, Brooks MW, Dougan M, Lambert AW, Bierie B, Ploegh HL, Dougan SK, Weinberg RA. The systemic response to surgery triggers the outgrowth of distant immune-controlled tumors in mouse models of dormancy. Sci Transl Med. 2018;10.

11. Guo W, Sun YF, Shen MN, Ma XL, Wu J, Zhang CY, Zhou Y, Xu Y, Hu B, Zhang $M$, et al. Circulating tumor cells with stem-like phenotypes for diagnosis, prognosis, and therapeutic response evaluation in hepatocellular carcinoma. Clin Cancer Res. 2018;24:2203-13.

12. Alimirzaie $S$, Bagherzadeh M, Akbari MR. Liquid biopsy in breast cancer: $A$ comprehensive review. Clin Genet. 2019.

13. Hanssen A, Riebensahm C, Mohme M, Joosse SA, Velthaus JL, Berger LA, Bernreuther C, Glatzel M, Loges S, Lamszus K, et al. Frequency of circulating tumor cells (ctc) in patients with brain metastases: implications as a risk assessment marker in oligo-metastatic disease. Cancers. 2018;10.

14. Schumacher S, Bartenhagen C, Hoffmann M, Will D, Fischer JC, Baldus SE, Vay C, Fluegen G, Dizdar L, Vallbohmer D, et al. Disseminated tumour cells with highly aberrant genomes are linked to poor prognosis in operable oesophageal adenocarcinoma. Brit J Cancer. 2017;117:725-33. 
15. Hoffmann M, Pasch S, Schamberger T, Maneck M, Mohlendick B, Schumacher S, Brockhoff G, Knoefel WT, Izbicki J, Polzer B, et al. Diagnostic pathology of early systemic cancer: ERBB2 gene amplification in single disseminated cancer cells determines patient survival in operable esophageal cancer. Int J Cancer. 2018;142:833-43.

16. Tvedskov TF, Jensen MB, Kroman N, Balslev E. latrogenic displacement of tumor cells to the sentinel node after surgical excision in primary breast cancer. Breast Cancer Res Treat. 2012;131:223-9.

17. Klein CA. Selection and adaptation during metastatic cancer progression. Nature. 2013;501:365-72.

18. Nagai S, Yoshida A, Facciuto M, Moonka D, Abouljoud MS, Schwartz ME, Florman SS. Ischemia time impacts recurrence of hepatocellular carcinoma after liver transplantation. Hepatology. 2015;61:895-904.

19. Kornberg A, Witt U, Kornberg J, Friess H, Thrum K. Extended ischemia times promote risk of hcc recurrence in liver transplant patients. Dig Dis Sci. 2015; 60:2832-9.

20. Wang J, Liu Y, Zhang AQ, Li CH, Dong JH. Inhibitory CpG sequences reduced ischemia/reperfusion-induced hepatic metastases of liver tumor in a murine model. J Surg Res. 2012;178:248-54.

21. Nijkamp MW, Hoogwater FJH, Govaert KM, Steller EJA, Verheem A, Kranenburg O, Rinkes IHMB. A role for cd95 signaling in ischemia/ reperfusion-induced invasion and outgrowth of colorectal micrometastases in mouse liver. J Surg Oncol. 2011;104:198-204.

22. Rodvold JJ, Mahadevan NR, Zanetti M. Lipocalin 2 in cancer: When good immunity goes bad. Cancer Lett. 2012;316:132-8.

23. Guo L, Li SY, Ji FY, Zhao YF, Zhong Y, Lv XJ, Wu XL, Qian GS. Role of Angptl4 in vascular permeability and inflammation. Inflamm Res. 2014;63:13-22.

24. Jung M, Mertens C, Bauer R, Rehwald C, Brune B. Lipocalin-2 and iron trafficking in the tumor microenvironment. Pharmacol Res. 2017;120:146-56.

25. Luster AD, Unkeless JC, Ravetch JV. Gamma-interferon transcriptionally regulates an early-response gene containing homology to platelet proteins. Nature. 1985;315:672-6.

26. Ling CC, Ng KTP, Shao Y, Geng W, Xiao JW, Liu H, Li CX, Liu XB, Ma YY, Yeung WH, et al. Post-transplant endothelial progenitor cell mobilization via CXCL10/ CXCR3 signaling promotes liver tumor growth. J Hepatol. 2014;60:103-9.

27. Nicoud IB, Jones CM, Pierce JM, Earl TM, Matrisian LM, Chari RS, Gorden DL. Warm hepatic ischemia-reperfusion promotes growth of colorectal carcinoma micrometastases in mouse liver via matrix metalloproteinase-9 induction. Cancer Res. 2007;67:2720-8.

28. Lenglet S, Mach F, Montecucco F. Matrix metalloproteinase-9: A deleterious link between hepatic ischemia-reperfusion and colorectal cancer. World J Gastroenterol. 2012;18:7131-3.

29. Yoshimoto K, Tajima H, Ohta T, Okamoto K, Sakai S, Kinoshita J, Furukawa H, Makino I, Hayashi H, Nakamura K, et al. Increased E-selectin in hepatic ischemia-reperfusion injury mediates liver metastasis of pancreatic cancer. Oncol Rep. 2012;28:791-6.

30. Honda M, Kubes P. Neutrophils and neutrophil extracellular traps in the liver and gastrointestinal system. Nat Rev Gastroenterol Hepatol. 2018;15:206-21.

31. Mancia G, Grassi G. The autonomic nervous system and hypertension. Circ Res. 2014;114:1804-14.

32. Cole SW, Nagaraja AS, Lutgendorf SK, Green PA, Sood AK. Sympathetic nervous system regulation of the tumour microenvironment. Nat Rev Cancer. 2015;15:563-72.

33. Gutierrez T, Hornigold R, Pearce A. The systemic response to surgery. Surgery. 2011;29:93-6.

34. Desborough JP. The stress response to trauma and surgery. Brit J Anaesthesia. 2000;85:109-17.

35. Moretti S, Massi D, Farini V, Baroni G, Parri M, Innocenti S, Cecchi R, Chiarugi $P$. beta-adrenoceptors are upregulated in human melanoma and their activation releases pro-tumorigenic cytokines and metalloproteases in melanoma cell lines. Lab Investig. 2013:93:279-90.

36. Le CP, Nowell CJ, Kim-Fuchs C, Botteri E, Hiller JG, Ismail H, Pimentel MA, Chai MG, Karnezis T, Rotmensz N, et al. Chronic stress in mice remodels lymph vasculature to promote tumour cell dissemination. Nat Commun. 2016;7.

37. Tsuchiya Y, Sawada S, Yoshioka I, Ohashi Y, Matsuo M, Harimaya Y, Tsukada K, Saiki I. Increased surgical stress promotes tumor metastasis. Surgery. 2003;133:547-55.

38. Mancino M, Ametller E, Gascon P, Almendro V. The neuronal influence on tumor progression. Biochim Biophys Acta. 1816;2011:105-18.

39. Creed SJ, Le CP, Hassan M, Pon CK, Albold S, Chan KT, Berginski ME, Huang Z, Bear JE, Lane JR, et al. beta2-adrenoceptor signaling regulates invadopodia formation to enhance tumor cell invasion. Breast Cancer Res. 2015;17:145.
40. Baldassarre M, Ayala I, Beznoussenko G, Giacchetti G, Machesky LM, Luini A, Buccione R. Actin dynamics at sites of extracellular matrix degradation. Eur J Cell Biol. 2006:85:1217-31.

41. Antoni MH, Lutgendorf SK, Cole SW, Dhabhar FS, Sephton SE, McDonald PG, Stefanek M, Sood AK. The influence of bio-behavioural factors on tumour biology: pathways and mechanisms. Nat Rev Cancer. 2006;6:240-8.

42. Masur K, Niggemann B, Zanker KS, Entschladen F. Norepinephrine-induced migration of SW 480 colon carcinoma cells is inhibited by beta-blockers. Cancer Res. 2001;61:2866-9.

43. Marusyk A, Polyak K. Tumor heterogeneity: Causes and consequences. Biochim Biophys Acta-Rev Cancer. 1805;2010:105-17.

44. Bernabe DG, Tamae AC, Biasoli ER, Oliveira SHP. Stress hormones increase cell proliferation and regulates interleukin- 6 secretion in human oral squamous cell carcinoma cells. Brain Behav Immun. 2011;25:574-83.

45. Thaker PH, Han LY, Kamat AA, Arevalo JM, Takahashi R, Lu C, Jennings NB, Armaiz-Pena G, Bankson JA, Ravoori M, et al. Chronic stress promotes tumor growth and angiogenesis in a mouse model of ovarian carcinoma. Nat Med. 2006;12:939-44.

46. Hondermarck $H$, Jobling $P$. The Sympathetic nervous system drives tumor angiogenesis. Trends Cancer. 2018;4:93-4.

47. Rosenne E, Sorski L, Shaashua L, Neeman E, Matzner P, Levi B, Ben-Eliyahu S. In vivo suppression of NK cell cytotoxicity by stress and surgery: Glucocorticoids have a minor role compared to catecholamines and prostaglandins. Brain Behav Immun. 2014;37:207-19.

48. Levi B, Matzner P, Goldfarb Y, Sorski L, Shaashua L, Melamed R, Rosenne E, Page GG, Ben-Eliyahu S. Stress impairs the efficacy of immune stimulation by CpG-C: Potential neuroendocrine mediating mechanisms and significance to tumor metastasis and the perioperative period. Brain Behav Immun. 2016;56:209-20.

49. Antonio N, Bonnelykke-Behrndtz ML, Ward LC, Collin J, Christensen IJ, Steiniche T, Schmidt H, Feng Y, Martin P. The wound inflammatory response exacerbates growth of pre-neoplastic cells and progression to cancer. EMBO J. 2015;34:2219-36.

50. Coussens LM, Werb Z. Inflammation and cancer. Nature. 2002:420:860-7.

51. Murdoch C, Muthana M, Coffelt SB, Lewis CE. The role of myeloid cells in the promotion of tumour angiogenesis. Nat Rev Cancer. 2008;8:618-31.

52. Sheng HM, Shao JY, Washington MK, DuBois RN. Prostaglandin E-2 increases growth and motility of colorectal carcinoma cells. J Biol Chem. 2001;276:18075-81.

53. Chang SH, Liu CH, Conway R, Han DK, Nithipatikom K, Trifan OC, Lane TF, Hla T. Role of prostaglandin E-2-dependent angiogenic switch in cyclooxygenase 2-induced breast cancer progression. Proc Natl Acad Sci U S A. 2004:101:591-6.

54. Zhang S, Da L, Yang X, Feng D, Yin R, Li M, Zhang Z, Jiang F, Xu L. Celecoxib potentially inhibits metastasis of lung cancer promoted by surgery in mice, via suppression of the PGE2-modulated beta-catenin pathway. Toxicol Lett. 2014;225:201-7.

55. Wang D, Dubois RN. Eicosanoids and cancer. Nat Rev Cancer. 2010;10:181-93.

56. Ruan D, So S-P. Prostaglandin E-2 produced by inducible COX-2 and mPGES-1 promoting cancer cell proliferation in vitro and in vivo. Life Sci. 2014;116:43-50.

57. Sosnoski DM, Norgard RJ, Grove CD, Foster SJ, Mastro AM. Dormancy and growth of metastatic breast cancer cells in a bone-like microenvironment. Clin Exp Metastasis. 2015;32:335-44.

58. Vidal AC, Howard LE, Moreira DM, Castro-Santamaria R, Andriole GL, Freedland SJ. Aspirin, NSAIDs, and risk of prostate cancer: results from the REDUCE study. Clin Cancer Res. 2015;21:756-62.

59. Mao JT, Smoake J, Park HK, Lu Q-Y, Xue B. Grape seed procyanidin extract mediates antineoplastic effects against lung cancer via modulations of prostacyclin and 15-hete eicosanoid pathways. Cancer Prev Res. 2016;9:925-32.

60. Pio R, Corrales L, Lambris JD. The role of complement in tumor growth. In Tumor Microenvironment and Cellular Stress: Signaling, Metabolism, Imaging, and Therapeutic Targets. Volume 772. Edited by Koumenis C, Hammond E, Giaccia A 2014: 229-262: Advances in Experimental Medicine and Biology.

61. Seol HS, Lee SE, Song JS, Rhee J-K, Singh SR, Chang S, Jang SJ. Complement proteins C7 and CFH control the stemness of liver cancer cells via LSF-1. Cancer Lett. 2016;372:24-35.

62. Bulla R, Tripodo C, Rami D, Ling GS, Agostinis C, Guarnotta C, Zorzet S, Durigutto $P$, Botto M, Tedesco F. C1q acts in the tumour microenvironment as a cancerpromoting factor independently of complement activation. Nat Commun. 2016;7.

63. Corrales L, Ajona D, Rafail S, Lasarte JJ, Riezu-Boj Jl, Lambris JD, Rouzaut A, Pajares MJ, Montuenga LM, Pio R. Anaphylatoxin C5a creates a favorable microenvironment for lung cancer progression. J Immunol. 2012;189:4674-83. 
64. Kwak JW, Laskowski J, Li HY, McSharry MV, Sippel TR, Bullock BL, Johnson AM, Poczobutt JM, Neuwelt AJ, Malkoski SP, et al. Complement activation via a C3a receptor pathway alters CD4(+) T lymphocytes and mediates lung cancer progression. Cancer Res. 2018;78:143-56.

65. Wang Y, Sun S-N, Liu Q, Yu Y-Y, Guo J, Wang K, Xing B-C, Zheng Q-F, Campa MJ, Patz EF Jr, et al. Autocrine complement inhibits il10-dependent t-cell-mediated antitumor immunity to promote tumor progression. Cancer Disc. 2016;6:1022-35.

66. Abdelbaset-Ismail A, Borkowska-Rzeszotek S, Kubis E, Bujko K, Brzezniakiewicz-Janus K, Bolkun L, Kloczko J, Moniuszko M, Basak GW, Wiktor-Jedrzejczak W, Ratajczak MZ. Activation of the complement cascade enhances motility of leukemic cells by downregulating expression of $\mathrm{HO}-1$. Leukemia. 2017;31:446-58.

67. Tsai JA, Lund M, Lundell L, Nilsson-Ekdahl K. One-lung ventilation during thoracoabdominal esophagectomy elicits complement activation. J Surg Res. 2009;152:331-7.

68. Kvarnstrom AL, Sarbinowski RT, Bengtson JP, Jacobsson LM, Bengtsson AL. Complement activation and interleukin response in major abdominal surgery. Scand J Immunol. 2012;75:510-6.

69. Xiong C, Liu J, Lin D, Zhang J, Terrando N, Wu A. Complement activation contributes to perioperative neurocognitive disorders in mice. $J$ Neuroinflammation. 2018;15:254.

70. Chiang SP, Cabrera RM, Segall JE. Tumor cell intravasation. Am J Phys Cell Phys. 2016;311:C1-C14.

71. Castell JV, Gomezlechon MJ, David M, Andus T, Geiger T, Trullenque R, Fabra R, Heinrich PC. Interleukin-6 is the major regulator of acute phase protein-synthesis in adult human hepatocytes. FEBS Lett. 1989;242:237-9.

72. Seth R, Tai LH, Falls T, de Souza CT, Bell JC, Carrier M, Atkins H, Boushey R, Auer RA. Surgical stress promotes the development of cancer metastases by a coagulation-dependent mechanism involving natural killer cells in a murine model. Ann Surg. 2013;258:158-68.

73. Dexter SPL, Griffith JP, Grant PJ, McMahon MJ. Activation of coagulation and fibrinolysis in open and laparoscopic cholecystectomy. Surg Endosc. 1996;10:1069-74.

74. Palumbo JS, Talmage KE, Massari JV, La Jeunesse CM, Flick MJ, Kombrinck KW, Jirouskova M, Degen JL. Platelets and fibrin(ogen) increase metastatic potential by impeding natural killer cell-mediated elimination of tumor cells. Blood. 2005;105:178-85.

75. Gay LJ, Felding-Habermann B. Contribution of platelets to tumour metastasis. Nat Rev Cancer. 2011;11:123-34.

76. Boonyawan K, Hess KR, Yang J, Long L, Wang Q, Ezhilarasan R, Auia A, Alfaro-Munoz KD, de Groot JF, Bhat KP, Sulman EP. A relative increase in circulating platelets following chemoradiation predicts for poor survival of patients with glioblastoma. Oncotarget. 2017;8:90488-95.

77. Hwang SG, Kim KM, Cheong JH, Kim HI, An JY, Hyung WJ, Noh SH. Impact of pretreatment thrombocytosis on blood-borne metastasis and prognosis of gastric cancer. Eur J Surg Oncol. 2012;38:562-7.

78. Paramanathan A, Saxena A, Morris DL. A systematic review and metaanalysis on the impact of pre-operative neutrophil lymphocyte ratio on long term outcomes after curative intent resection of solid tumours. Surg Oncol. 2014;23:31-9.

79. Orellana R, Kato S, Erices R, Bravo ML, Gonzalez P, Oliva B, Cubillos S, Valdivia A, Ibanez C, Branes J, et al. Platelets enhance tissue factor protein and metastasis initiating cell markers, and act as chemoattractants increasing the migration of ovarian cancer cells. BMC Cancer. 2015;15:290.

80. Liang $H$, Yang C, Zhang B, Wang H, Liu H, Zhao Z, Zhang Z, Wen X, Lai X. Hydroxyethyl starch 200/0.5 decreases circulating tumor cells of colorectal cancer patients and reduces metastatic potential of colon cancer cell line through inhibiting platelets activation. Med Oncol. 2015;32:151.

81. Burnet FM. Concept of immunological surveillance. Prog Exp Tumor Res. 1970;13:1.

82. Ogawa K, Hirai M, Katsube T, Murayama H, Hamaguchi K, Shimakawa T, Naritake Y, Hosokawa T, Kajiwara T. Suppression of cellular immunity by surgical stress. Surgery. 2000;127:329-36.

83. Shakhar G, Ben-Eliyahu S. Potential prophylactic measures against postoperative immunosuppression. Could they reduce recurrence rates in oncological patients? Ann Surg Oncol. 2003;10:972-92.

84. Wolf AM, Wolf D, Steurer M, Gastl G, Gunsilius E, Grubeck-Loebenstein B. Increase of regulatory $T$ cells in the peripheral blood of cancer patients. Clin Cancer Res. 2003;9:606-12.

85. Decker T, Fischer G, Bucke W, Bucke P, Stotz F, Gruneberger A, Gropp-Meier M, Wiedemann G, Pfeiffer C, Peschel C, Gotze K. Increased number of regulatory $T$ cells (T-regs) in the peripheral blood of patients with Her-2/ neu-positive early breast cancer. J Cancer Res Clin Oncol. 2012;138:1945-50.
86. Phillips JD, Knab LM, Blatner NR, Haghi L, DeCamp MM, Meyerson SL, Heiferman MJ, Heiferman JR, Gounari F, Bentrem DJ, Khazaie K. Preferential expansion of pro-inflammatory Tregs in human non-small cell lung cancer. Cancer Immunol Immunother. 2015;64:1185-91.

87. Saito $Y$, Shimada M, Utsunomiya T, Morine $Y$, Imura S, Ikemoto T, Mori H, Hanaoka J, Iwahashi S, Yamada S, Asanoma M. Regulatory T cells in the blood: a new marker of surgical stress. Surg Today. 2013;43:608-12.

88. Lissoni P, Brivio F, Fumagalli L, Messina G, Meregalli S, Porro G, Rovelli F, Vigore L, Tisi E, D'Amico G. Effects of the conventional antitumor therapies surgery, chemotherapy, radiotherapy and immunotherapy on regulatory $t$ lymphocytes in cancer patients. Anticancer Res. 2009;29:1847-52.

89. Albertsmeier M, Quaiser D, von Dossow-Hanfstingl V, Winter H, Faist E, Angele MK. Major surgical trauma differentially affects T-cells and APC. Innate Immun. 2015;21:55-64.

90. Cote AL, Usherwood EJ, Turk MJ. Tumor-specific T-cell memory: clearing the regulatory T-cell hurdle. Cancer Res. 2008;68:1614-7.

91. Gao XH, Tian L, Wu J, Ma XL, Zhang CY, Zhou Y, Sun YF, Hu B, Qiu SJ, Zhou J, et al. Circulating CD14(+)HLA-DR-/low myeloid-derived suppressor cells predicted early recurrence of hepatocellular carcinoma after surgery. Hepatol Res. 2017:47:1061-71.

92. Li W, Wu K, Zhao ED, Shi L, Li RD, Zhang P, Yin YP, Shuai XM, Wang GB, Tao KX. HMGB1 recruits myeloid derived suppressor cells to promote peritoneal dissemination of colon cancer after resection. Biochem Biophys Res Commun. 2013;436:156-61.

93. Ananth AA, Tai LH, Lansdell C, Alkayyal AA, Baxter KE, Angka L, Zhang J, Tanese de Souza C, Stephenson KB, Parato K, et al. Surgical stress abrogates pre-existing protective $t$ cell mediated anti-tumor immunity leading to postoperative cancer recurrence. PLoS One. 2016;11:e0155947.

94. Wang J, Su XS, Yang L, Qiao F, Fang Y, Yu L, Yang Q, Wang YY, Yin YF, Chen R, Hong ZP. The influence of myeloid-derived suppressor cells on angiogenesis and tumor growth after cancer surgery. Int J Cancer. 2016;138:2688-99.

95. Condamine T, Ramachandran I, Youn Jl, Gabrilovich DI. Regulation of tumor metastasis by myeloid-derived suppressor cells. Annu Rev Med. 2015;66:97-110.

96. Tai LH, Alkayyal AA, Leslie AL, Sahi S, Bennett S, de Souza CT, Baxter K, Angka L, Xu R, Kennedy MA, Auer RC. Phosphodiesterase-5 inhibition reduces postoperative metastatic disease by targeting surgery-induced myeloid derived suppressor cell-dependent inhibition of natural killer cell cytotoxicity. Oncoimmunology. 2018;7.

97. Espi A, Arenas J, GarciaGranero E, Marti E, Lledo S. Relationship of curative surgery on natural killer cell activity in colorectal cancer. Dis Colon Rectum. 1996;39:429-34.

98. Angka L, Martel AB, Kilgour M, Jeong A, Sadiq M, de Souza CT, Baker L, Kennedy MA, Kekre N, Auer RC. Natural killer cell ifn gamma secretion is profoundly suppressed following colorectal cancer surgery. Ann Surg Oncol. 2018;25:3747-54.

99. Ben-Eliyahu S, Shakhar G, Page GG, Stefanski V, Shakhar K. Suppression of NK cell activity and of resistance to metastasis by stress: A role for adrenal catecholamines and beta-adrenoceptors. Neuroimmunomodulation. 2000;8:154-64.

100. Meron G, Tishler Y, Shaashua L, Rosenne E, Levi B, Melamed R, Gotlieb N, Matzner P, Sorski L, Ben-Eliyahu S. PGE(2) suppresses NK activity in vivo directly and through adrenal hormones: Effects that cannot be reflected by ex vivo assessment of NK cytotoxicity. Brain Behav Immun. 2013;28:128-38.

101. Pollock RE, Lotzova E, Stanford SD. Surgical stress impairs natural-killer-cell programming of tumor for lysis in patients with sarcomas and other solid tumors. Cancer. 1992;70:2192-202.

102. McDonald B, Spicer J, Giannais B, Fallavollita L, Brodt P, Ferri LE. Systemic inflammation increases cancer cell adhesion to hepatic sinusoids by neutrophil mediated mechanisms. Int J Cancer. 2009;125:1298-305.

103. Ten Kate M, Aalbers AGJ, Sluiter W, Hofland LJ, Sonneveld P, Jeekel J, Van Eijck $\mathrm{CHJ}$. Polymorphonuclear leukocytes increase the adhesion of circulating tumor cells to microvascular endothelium. Anticancer Res. 2007;27:17-22.

104. Szczerba BM, Castro-Giner F, Vetter M, Krol I, Gkountela S, Landin J, Scheidmann MC Donato C, Scherrer R, Singer J, et al. Neutrophils escort circulating tumour cells to enable cell cycle progression. Nature. 2019;566:553-7.

105. Lord JM, Midwinter MJ, Chen Y-F, Belli A, Brohi K, Kovacs EJ, Koenderman L, Kubes $P$, Lilford RJ. The systemic immune response to trauma: an overview of pathophysiology and treatment. Lancet. 2014;384:1455-65.

106. Jorch SK, Kubes P. An emerging role for neutrophil extracellular traps in noninfectious disease. Nat Med. 2017;23:279-87.

107. Tohme S, Yazdani HO, Al-Khafaji AB, Chidi AP, Loughran P, Mowen K, Wang $Y$, Simmons RL, Huang $H$, Tsung A. Neutrophil extracellular traps promote the development and progression of liver metastases after surgical stress. Cancer Res. 2016;76:1367-80. 
108. Albrengues J, Shields MA, Ng D, Park CG, Ambrico A, Poindexter ME, Upadhyay P, Uyeminami DL, Pommier A, Kuttner V, et al. Neutrophil extracellular traps produced during inflammation awaken dormant cancer cells in mice. Science. 2018;361.

109. Huang H, Tohme S, Al-Khafaji AB, Tai S, Loughran P, Chen L, Wang S, Kim J, Billiar T, Wang Y, Tsung A. Damage-associated molecular pattern-activated neutrophil extracellular trap exacerbates sterile inflammatory liver injury. Hepatology. 2015;62:600-14.

110. Snyder GL, Greenberg S. Effect of anaesthetic technique and other perioperative factors on cancer recurrence. Br J Anaesth. 2010;105:106-15.

111. Shapiro J, Jersky J, Katzav S, Feldman M, Segal S. Anesthetic drugs accelerate the progression of postoperative metastases of mouse tumors. J Clin Invest. 1981;68:678-85.

112. Tavare AN, Perry NJ, Benzonana LL, Takata M, Ma D. Cancer recurrence after surgery: direct and indirect effects of anesthetic agents. Int J Cancer. 2012;130:1237-50

113. Buljubasic N, Rusch NJ, Marijic J, Kampine JP, Bosnjak ZJ. Effects of halothane and isoflurane on calcium and potassium channel currents in canine coronary arterial cells. Anesthesiology. 1992;76:990-8.

114. Benzonana LL, Perry NJS, Ma D. Potential role of the PI3K pathway on renal cell carcinoma progression in vitro. Brit J Anaesth. 2011;106:428P.

115. Elena G, Amerio N, Ferrero P, Bay ML, Valenti J, Colucci D, Puig NR. Effects of repetitive sevoflurane anaesthesia on immune response, select biochemical parameters and organ histology in mice. Lab Anim. 2003;37:193-203.

116. Desmond F, McCormack J, Mulligan N, Stokes M, Buggy DJ. Effect of anaesthetic technique on immune cell infiltration in breast cancer: a followup pilot analysis of a prospective, randomised, investigator-masked study. Anticancer Res. 2015;35:1311-9.

117. Zhu M, Li M, Zhou Y, Dangelmajer S, Kahlert UD, Xie R, Xi Q, Shahveranov A, Ye D, Lei T. Isoflurane enhances the malignant potential of glioblastoma stem cells by promoting their viability, mobility in vitro and migratory capacity in vivo. Br J Anaesth. 2016;116:870-7.

118. Yamakura T, Harris RA. Effects of gaseous anesthetics nitrous oxide and xenon on ligand-gated ion channels. Comparison with isoflurane and ethanol. Anesthesiology. 2000;93:1095-101.

119. Mennerick S, Jevtovic-Todorovic V, Todorovic SM, Shen W, Olney JW, Zorumski CF. Effect of nitrous oxide on excitatory and inhibitory synaptic transmission in hippocampal cultures. J Neurosci. 1998;18:9716-26.

120. Rupertus K, Sperling J, Corsten M, Scheuer C, Nickels RM, Schilling MK, Menger MD, Kollmar O. Darbepoetin-alpha enhances hepatectomyassociated stimulation of colorectal liver metastatic growth. Ann Surg. 2010; 252:131-41.

121. Wigmore TJ, Mohammed K, Jhanji S. Long-term survival for patients undergoing volatile versus iv anesthesia for cancer surgery. Anesthesiology. 2016;124:69-79.

122. Green SM, Roback MG, Kennedy RM, Krauss B. Clinical practice guideline for emergency department ketamine dissociative sedation: 2011 update. Ann Emerg Med. 2011;57:449-61.

123. Tyler MW, Yourish HB, lonescu DF, Haggarty SJ. Classics in chemical neuroscience: ketamine. ACS Chem Neurosci. 2017:8:1122-34.

124. Melamed R, Bar-Yosef S, Shakhar G, Shakhar K, Ben-Eliyahu S. Suppression of natural killer cell activity and promotion of tumor metastasis by ketamine, thiopental, and halothane, but not by propofol: Mediating mechanisms and prophylactic measures. Anesth Analg. 2003;97:1331-9.

125. Weber M, Motin L, Gaul S, Beker F, Fink RHA, Adams DJ. Intravenous anaesthetics inhibit nicotinic acetylcholine receptor-mediated currents and Ca2+ transients in rat intracardiac ganglion neurons. Brit J Pharmacol. 2005;144:98-107.

126. Loop T, Humar M, Pischke S, Hoetzel A, Schmidt R, Pahl HL, Geiger KK, Pannen BHJ. Thiopental inhibits tumor necrosis factor alpha-induced activation of nuclear factor kappa B through suppression of I kappa B kinase activity. Anesthesiology. 2003;99:360-7.

127. Tanaka T, Takabuchi S, Nishi K, Oda S, Wakamatsu T, Daijo H, Fukuda K Hirota K. The intravenous anesthetic propofol inhibits lipopolysaccharideinduced hypoxia-inducible factor 1 activation and suppresses the glucose metabolism in macrophages. J Anesth. 2010;24:54-60.

128. Mammoto T, Mukai M, Mammoto A, Yamanaka Y, Hayashi Y, Mashimo T, Kishi $Y$, Nakamura $\mathrm{H}$. Intravenous anesthetic, propofol inhibits invasion of cancer cells. Cancer Lett. 2002;184:165-70.

129. Siddiqui RA, Zerouga M, Wu M, Castillo A, Harvey K, Zaloga GP, Stillwell W. Anticancer properties of propofol-docosahexaenoate and propofoleicosapentaenoate on breast cancer cells. Breast Cancer Res. 2005;7: R645-54.
130. Christopherson R, James KE, Tableman M, Marshall P, Johnson FE. Lona-term survival after colon cancer surgery. A variation associated with choice of anesthesia. Anesth Analg. 2008;107:325-32.

131. Biki B, Mascha E, Moriarty DC, Fitzpatrick JM, Sessler DI, Buggy DJ. Anesthetic technique for radical prostatectomy surgery affects cancer recurrence - A retrospective analysis. Anesthesiology. 2008;109:180-7.

132. Diaz ES, Karlan BY, Li AJ. Impact of beta blockers on epithelial ovarian cancer survival. Gynecol Oncol. 2012;127:375-8.

133. Storch $\mathrm{CH}$, Hoeger $\mathrm{PH}$. Propranolol for infantile haemangiomas: insights into the molecular mechanisms of action. Br J Dermatol. 2010;163:269-74.

134. Al-Niaimi A, Dickson EL, Albertin C, Karnowski J, Niemi C, Spencer R, Shahzad MM, Uppal S, Saha S, Rice L, Nally AM. The impact of perioperative beta blocker use on patient outcomes after primary cytoreductive surgery in high-grade epithelial ovarian carcinoma. Gynecol Oncol. 2016;143:521-5.

135. Choy C, Raytis JL, Smith DD, Duenas M, Neman J, Jandial R, Lew MW. Inhibition of beta(2)-adrenergic receptor reduces triple-negative breast cancer brain metastases: The potential benefit of perioperative betablockade. Oncol Rep. 2016;35:3135-42.

136. Zhou L, Li Y, Li X, Chen G, Liang H, Wu Y, Tong J, Ouyang W. Propranolol attenuates surgical stress-induced elevation of the regulatory $t$ cell response in patients undergoing radical mastectomy. J Immunol. 2016;196:3460-9.

137. Ricon I, Hanalis-Miller T, Haldar R, Jacoby R, Ben-Eliyahu S. Perioperative biobehavioral interventions to prevent cancer recurrence through combined inhibition of betaadrenergic and cyclooxygenase 2 signaling. Cancer. 2019;125:45-56.

138. Thompson PA, Ashbeck EL, Roe DJ, Fales L, Buckmeier J, Wang F, Bhattacharyya A, Hsu C-H, Chow SHH, Ahnen DJ, et al. Celecoxib for the prevention of colorectal adenomas: results of a suspended randomized controlled trial. J Natl Cancer Inst. 2016;108.

139. Ma W, Wang K, Du J, Luan J, Lou G. Multi-dose parecoxib provides an immunoprotective effect by balancing T helper 1 (Th1), Th2, Th17 and regulatory $T$ cytokines following laparoscopy in patients with cervical cancer. Mol Med Rep. 2015;11:2999-3008.

140. Domingo E, Church DN, Sieber O, Ramamoorthy R, Yanagisawa Y, Johnstone E, Davidson B, Kerr DJ, Tomlinson IPM, Midgley R. Evaluation of PIK3CA mutation as a predictor of benefit from nonsteroidal anti-Inflammatory drug therapy in colorectal cancer. J Clin Oncol. 2013;31:4297-U4234.

141. Petrera M, Paleari L, Clavarezza M, Puntoni M, Caviglia S, Briata IM, Oppezzi M, Mislej EM, Stabuc B, Gnant M, et al. The ASAMET trial: a randomized, phase II, double-blind, placebo-controlled, multicenter, 2×2 factorial biomarker study of tertiary prevention with low-dose aspirin and metformin in stage I-III colorectal cancer patients. BMC Cancer. 2018;18.

142. Matzner P, Sorski L, Shaashua L, Elbaz E, Lavon H, Melamed R, Rosenne E, Gotlieb N, Benbenishty A, Reed SG, Ben-Eliyahu S. Perioperative treatment with the new synthetic TLR-4 agonist GLA-SE reduces cancer metastasis without adverse effects. Int J Cancer. 2016;138:1754-64.

143. Goldfarb Y, Benish M, Rosenne E, Melamed R, Levi B, Glasner A, Ben-Eliyahu S. CpG-C oligodeoxynucleotides limit the deleterious effects of betaadrenoceptor stimulation on nk cytotoxicity and metastatic dissemination. $J$ Immunother. 2009:32:280-91.

144. Tai L-H, Zhang J, Scott KJ, de Souza CT, Alkayyal AA, Ananth AA, Sahi S, Adair RA, Mahmoud AB, Sad S, et al. Perioperative influenza vaccination reduces postoperative metastatic disease by reversing surgery-induced dysfunction in natural killer cells. Clin Cancer Res. 2013;19:5104-15.

145. Bartal I, Melamed R, Greenfeld K, Atzil S, Glasner A, Domankevich V, Naor R, Beilin B, Yardeni IZ, Ben-Eliyahu S. Immune perturbations in patients along the perioperative period: Alterations in cell surface markers and leukocyte subtypes before and after surgery. Brain Behav Immun. 2010;24:376-86.

146. Bohle W, Schlag P, Liebrich W, Hohenberger P, Manasterski M, Moller P, Schirrmacher V. Postoperative active specific immunization in colorectalcancer patients with virus-modified autologous tumor-cell vaccine - 1st clinical-results with tumor-cell vaccines modified with live but avirulent newcastle-disease virus. Cancer. 1990;66:1517-23.

147. Schirrmacher V. Clinical trials of antitumor vaccination with an autologous tumor cell vaccine modified by virus infection: improvement of patient survival based on improved antitumor immune memory. Cancer Immunol Immunother. 2005;54:587-98.

148. Bakos O, Lawson C, Rouleau S, Tai LH. Combining surgery and immunotherapy: turning an immunosuppressive effect into a therapeutic opportunity. J Immunother Cancer. 2018;6:86.

149. Chan WWN, Wong GTC, Irwin MG. Perioperative statin therapy. Expert Opin Pharmacother. 2013;14:831-42. 
150. Esumi N, Fan D, Fidler IJ. Inhibition of murine melanoma experimental metastasis by recombinant desulfatohirudin, a highly specific thrombin inhibitor. Cancer Res. 1991;51:4549-56.

151. Hu L, Lee M, Campbell W, Perez-Soler R, Karpatkin S. Role of endogenous thrombin in tumor implantation, seeding, and spontaneous metastasis. Blood. 2004;104:2746-51.

152. Tieken C, Versteeg HH. Anticoagulants versus cancer. Thromb Res. 2016;140:S148-53.

153. Renaud S, Schaeffer M, Falcoz PE, Seitlinger J, Romain B, Voegeli AC, Legrain M, Reeb J, Santelmo N, Rohr S, et al. Perioperative bevacizumab improves survival following lung metastasectomy for colorectal cancer in patients harbouring v-Ki-ras2 Kirsten rat sarcoma viral oncogene homologue exon 2 codon 12 mutationsdagger. Eur J Cardiothorac Surg. 2017;51:255-62.

154. Bonten TN, Plaizier CE, Snoep JJ, Stijnen T, Dekkers OM, van der Bom JG. Effect of beta-blockers on platelet aggregation: a systematic review and meta-analysis. Br J Clin Pharmacol. 2014;78:940-9.

155. Hiller JG, Perry NJ, Poulogiannis G, Riedel B, Sloan EK. Perioperative events influence cancer recurrence risk after surgery. Nat Rev Clin Oncol. 2018;15:205-18.

156. Glasner A, Avraham R, Rosenne E, Benish M, Zmora O, Shemer S, Meiboom H, Ben-Eliyahu S. Improving survival rates in two models of spontaneous postoperative metastasis in mice by combined administration of a beta-adrenergic antagonist and a cyclooxygenase-2 inhibitor. J Immunol. 2010; 184:2449-57.

157. Yakar I, Melamed R, Shakhar G, Shakhar K, Rosenne E, Abudarham N, Page GG, Ben-Eliyahu S. Prostaglandin E-2 suppresses NK activity in vivo and promotes postoperative tumor metastasis in rats. Ann Surg Oncol. 2003;10:469-79.

158. Flamiatos JF, Beer TM, Graff JN, Eilers KM, Tian W, Sekhon HS, Garzotto M. Cyclooxygenase-2 (COX-2) inhibition for prostate cancer chemoprevention: double-blind randomised study of pre-prostatectomy celecoxib or placebo. BJU Int. 2017;119:709-16.

159. Aristarco V, Serrano D, Gandini S, Johansson H, Macis D, Guerrieri-Gonzaga A, Lazzeroni M, Feroce I, Pruneri G, Pagani G, et al. A randomized, placebocontrolled, phase ii, presurgical biomarker trial of celecoxib versus exemestane in postmenopausal breast cancer patients. Cancer Prev Res. 2016;9:349-56

160. Martin L-A, Davies GLS, Weigel MT, Betambeau N, Hills MJ, Salter J, Walsh G, A'Hern R, Dowsett M. Pre-surgical study of the biological effects of the selective cyclo-oxygenase-2 inhibitor celecoxib in patients with primary breast cancer. Breast Cancer Res Treat. 2010;123:829-36.

161. Grabosch SM, Shariff OM, Helm CW. Non-steroidal anti-inflammatory agents to induce regression and prevent the progression of cervical intraepithelial neoplasia. Cochrane Database Syst Rev. 2018;2:CD004121.

162. Lv N, Kong Y, Mu L, Pan T, Xie Q, Zhao M. Effect of perioperative parecoxib sodium on postoperative pain control for transcatheter arterial chemoembolization for inoperable hepatocellular carcinoma: a prospective randomized trial. Eur Radiol. 2016;26:3492-9.

163. Pandazi A, Kapota E, Matsota P, Paraskevopoulou P, Dervenis C Kostopanagiotou G. Preincisional versus postincisional administration of parecoxib in colorectal surgery: effect on postoperative pain control and cytokine response. a randomized clinical trial. World J Surg. 2010;34:2463-9.

164. Delneste $Y$, Beauvillain C, Jeannin P. Innate immunity: structure and function of TLRs. Med Sci. 2007;23:67-73.

\section{Publisher's Note}

Springer Nature remains neutral with regard to jurisdictional claims in published maps and institutional affiliations.

Ready to submit your research? Choose BMC and benefit from:

- fast, convenient online submission

- thorough peer review by experienced researchers in your field

- rapid publication on acceptance

- support for research data, including large and complex data types

- gold Open Access which fosters wider collaboration and increased citations

- maximum visibility for your research: over $100 \mathrm{M}$ website views per year

At $\mathrm{BMC}$, research is always in progress.

Learn more biomedcentral.com/submissions 